BMJ Open Sport \& Exercise Medicine

\title{
Effects of body protection vests and experience levels in prevention of equestrian injuries
}

\author{
Sarah A Andres, ${ }^{1,2}$ Adrienne M Bushau-Sprinkle, ${ }^{2,3}$ Michael E Brier, ${ }^{1}$ \\ Yvette R Seger 2,4
}

To cite: Andres SA, Bushau-Sprinkle AM, Brier ME, et al. Effects of body protection vests and experience levels in prevention of equestrian injuries. BMJ Open Sport \& Exercise Medicine 2018;4:e000426. doi:10.1136/ bmjsem-2018-000426

- Additional material is published online only. To view please visit the journal online (http://dx.doi.org/10.1136/ bmjsem-2018-000426).

Accepted 3 October 2018

Check for updates

(c) Author(s) (or their employer(s)) 2018. Re-use permitted under CC BY-NC. No commercial re-use. See rights and permissions. Published by BMJ.

${ }^{1}$ Department of Medicine, University of Louisville, Louisville, Kentucky, USA ${ }^{2}$ United States Pony Clubs, Lexington, Kentucky, USA ${ }^{3}$ Department of Pharmacology and Toxicology, University of Louisville, Louisville, Kentucky, USA

${ }^{4}$ Office of Public Affairs, Federation of American Societies for Experimental Biology, Bethesda, Maryland, USA

Correspondence to Sarah A Andres; sarah.andres@ louisville.edu

\section{ABSTRACT}

Objectives To investigate the risk reduction and benefit of wearing body protection/safety vests in equestrian sports.

Methods A comparison of equestrians wearing body protective vests and those not wearing vests was performed using incident report data of 718 participants in the United States Pony Clubs during 2011-2017. Data obtained included age, gender, certification level of member, type of activity, description of incident, description of injuries, what protective equipment was worn and other possible contributing factors.

Results While wearing body protective vests when riding on the flat or for show jumping was not correlated with a decrease in injuries, wearing vests for cross country was correlated with decrease in reported injuries $(p=0.036)$ and showed a trend towards a lower incident severity level $(p=0.062)$. Wearing body protection during cross country reduced the relative risk of injury by $56 \%$. While the volume of incidents varied with a rider's experience level, the number of serious injuries did not appear to correlate with lesser equestrian experience.

Conclusions While equestrian sports are considered to have a certain degree of risk associated with them, there are ways to make them safer. Wearing safety equipment, such as helmets and body protection, and obtaining education and experience can lessen the chance of incurring serious injuries.

\section{INTRODUCTION}

Previous studies regarding the safety of equestrians have focused on the high incidence of head injuries, especially compared with other sports. ${ }^{12}$ These studies discussed the lack of helmet use in equestrian sports as a primary reason for the increased incidence of concussion. ${ }^{1-5}$ While studies have reported that head injuries account for between $13 \%$ and $48 \%$ of equestrian-related injuries, ${ }^{6-11}$ injuries to the chest or back have been reported in $11 \%-54 \%$ of equestrian cases..$^{5-12}$

The United States Equestrian Federation (USEF) and the United States Eventing Association (USEA) first recommended the use of body protecting vests for the cross country phase in the sport of eventing in 1994, and
What are the new findings?

- An analysis was performed that illustrates a statistically significant decrease in equestrian injuries when body protection is worn during cross country activities, but not other types of riding.

- A trend towards less severe injuries was observed when body protection was worn for cross country riding.

While the amount of incidents varied with a riders experience level, the amount of serious injuries did not appear to be correlated with lesser equestrian experience.

later made their use mandatory in $1996 .{ }^{8}$ While the USEA/USEF do not currently require the use of an American Society for Testing and Materials (ASTM)-approved body protection vest for cross country jumping, British Eventing currently requires use of a body protector with at least British Equestrian Trade Organization (BETA) Level 3 certification. This is the highest level of protection recognised by BETA and is considered appropriate for general riding and competitions. BETA states that Level 3 body protectors should prevent minor bruising that would have produced stiffness and pain, reduce soft tissue injuries and prevent a limited number of rib fractures, while Level 2 offers lower than normal protection and Level 1 offers the least protection, but is designed to meet the weight restrictions that apply to jockeys when racing.

While numerous studies have demonstrated that wearing helmets dramatically reduces the risk of head injury, few studies have investigated the risk reduction of wearing other safety equipment, such as body protectors/ safety vests. Although some studies mentioned the use of body protection, ${ }^{212}$ few studies have investigated the benefit of body protection in equestrian sports. ${ }^{10} 13$ A study by Hessler et $a l^{13}$ found there was no association between wearing body protection and protection from 
torso injuries in a study of 92 paediatric and adolescent equestrians. However, this study did not investigate the effects of wearing body protection in specific equestrian activities, such as show jumping and cross country.

The United States Pony Clubs (USPC) has been recognised as a leader in equestrian safety, since they were the first organisation to require their members to wear helmets when mounted, ${ }^{78}$ and they aided in the development of the ASTM equestrian helmet standard F1163 in 1988. The USPC has collected a detailed database of incident reports and is in a unique position in that, while the organisation recommends the use of body protection vests, it has not made their use mandatory when riding at USPC activities due to the lack of scientific evidence of efficacy. Incident report data from this organisation allows the effectiveness of body protectors to be evaluated in its primarily youth population.

\section{METHODS}

\section{Incident report data}

USPC District Commissioners, Center Administrators or other leaders fill out an online or print version of an incident report form which is entered into a national database. Data elements on the forms include age, gender, certification level of member, type of activity, description of incident, description of injuries, what protective equipment was being worn and other possible contributing factors. A retrospective review of USPC's incident reports from 2011 to 2017 was conducted in this study. Each incident was given an ordinal severity level based on information received in the report: $0=$ no injury observed or required no treatment; $1=$ required treatment and continued with activity; $2=$ required treatment but declined to continue with activity; $3=$ serious injury. $\chi^{2}$ and ordinal regression analyses were performed using SPSS V.24 software. P values of less than 0.05 were considered statistically significant.

\section{Safety vest survey of membership}

To better understand the current use and views of safety vests within USPC membership, an online survey was developed using SurveyMonkey (see online supplementary material 1). A link to the survey was sent directly to all USPC members' emails. Responses were received from 890 members, representing approximately $10 \%$ of the total USPC membership.

\section{RESULTS}

\section{Incident demographics}

Of the 718 incidents reported from 2011 to 2017, over $91.6 \%$ (658) indicated that the person associated was mounted on a horse when the incident occurred, which is similar to previous accounts. ${ }^{15}$ These mounted reports were analysed in this study (table 1). Among the reports of mounted incidents, $25.0 \%$ of the riders were wearing protective vests, while $75.0 \%$ were not wearing one at the time the accident occurred. More people choose to wear protective vests when participating in jumping sports compared with non-jumping sports $(30.8 \%$ and $10.0 \%$, respectively), and within the jumping sports, many more people wore vests when riding cross country compared with show jumping $(70.7 \%$ and $7.5 \%$, respectively). The average age and gender of the riders were not significantly different in all the groups evaluated ( $p$ value for age $=0.35$ ).

\section{Differences in outcomes observed when wearing body protection vests}

Initial analyses to determine if wearing body protection had an effect on whether or not a rider was injured were performed. When comparing riders in all mounted activities wearing a body protector to riders who did not wear a vest (table 2), there was not a statistically significant difference between riders who sustained an injury compared with those who did not ( $p$ value $=0.18$ ).

In general, jumping is considered to be more dangerous than riding on the flat (ie, riding without jumps). Because of this, USEF required protective headgear for all sanctioned jumping competitions beginning in $1964,{ }^{8}$ while helmets were only required at lower levels of dressage since 2013; helmets are still not required in the international western discipline of reining or vaulting. Since there appears to be a difference in risk between riding on the flat and jumping, those activities were evaluated separately. Among riders participating in non-jumping activities (table 2), there was no statistical difference in injuries observed $(\mathrm{p}=0.29)$. Among riders participating in jumping sports (table 2), there also was no statistical difference in injuries observed $(p=0.67)$.

Since traditionally body protection is worn almost exclusively in the cross country (XC) phase of eventing, we wanted to ensure any results obtained were not

\begin{tabular}{|c|c|c|c|c|c|c|}
\hline & \multirow{2}{*}{$\begin{array}{l}\text { Total numbers of } \\
\text { reported mounted } \\
\text { incidents }\end{array}$} & \multirow{2}{*}{$\begin{array}{l}\text { Median age of rider } \\
\text { affected }\end{array}$} & \multicolumn{2}{|c|}{ Gender of rider } & \multirow{2}{*}{$\begin{array}{l}\text { No. reported } \\
\text { incidents wearing } \\
\text { body protection }\end{array}$} & \multirow{2}{*}{$\begin{array}{l}\text { No. Reported } \\
\text { incidents not wearing } \\
\text { body protection }\end{array}$} \\
\hline & & & Female & Male & & \\
\hline All mounted activities & 658 & 14 (range of $5-65$ ) & $95.0 \%$ & $5.0 \%$ & $165(25.0 \%)$ & $493(75.0 \%)$ \\
\hline Riders not in jumping disciplines & 170 & 13 (range of $5-57$ ) & $90.6 \%$ & $9.4 \%$ & $17(10.0 \%)$ & $153(90.0 \%)$ \\
\hline Riders in jumping disciplines & 484 & 14 (range of 7-65) & $96.9 \%$ & $3.1 \%$ & $149(30.8 \%)$ & $335(69.2 \%)$ \\
\hline Show jumping & 306 & 14 (range of 7-65) & $97.1 \%$ & $2.9 \%$ & $23(7.5 \%)$ & $283(92.5 \%)$ \\
\hline Cross country & 174 & 14 (range of 7-64) & $97.7 \%$ & $2.3 \%$ & $123(70.7 \%)$ & $51(29.3 \%)$ \\
\hline
\end{tabular}


Table 2 Pearson $\chi^{2}$ analysis of outcomes observed when wearing body protection vests in different Equestrian activities

\begin{tabular}{|cl|}
\hline & P values \\
\hline All mounted activities & 0.18 \\
\hline Riders not in jumping disciplines & 0.29 \\
\hline Riders in jumping disciplines & 0.67 \\
\hline Show jumping & 0.86 \\
\hline Cross country & 0.036 \\
\hline
\end{tabular}

simply due to cross country being a higher risk equestrian activity than show jumping, in which the poles fall down when hit by the horse. ${ }^{816} 17$ When evaluating the differences in outcomes for riders wearing safety vests in show jumping (table 2), there is no significant difference observed $(p=0.86)$. It should be noted that of the riders participating in show jumping $(n=281)$, only 23 riders wore a vest, which may have affected the lack of difference observed. A similar analysis of equestrians participating in cross country riding had a different outcome (table 2). Riders who wore a vest for cross country had a decrease in injuries observed compared with those who did not wear a vest. Wearing vests for cross country was correlated with a decrease in reported injuries $(\mathrm{p}=0.036)$ and reduced the relative risk of injury by $56 \%$ (relative risk $=0.64,95 \%$ CI 0.43 to 0.96 ).

To investigate the difference in outcome associated with wearing body protective vests, incident severity levels were determined based on information provided in the incident reports with 0 indicating no injury observed or required no treatment, and an incident severity level of 3 indicating a serious injury occurred. An ordinal regression analysis was performed to evaluate the effect of wearing body protection on the incident severity level. While not statistically significant, there was a trend towards a lower

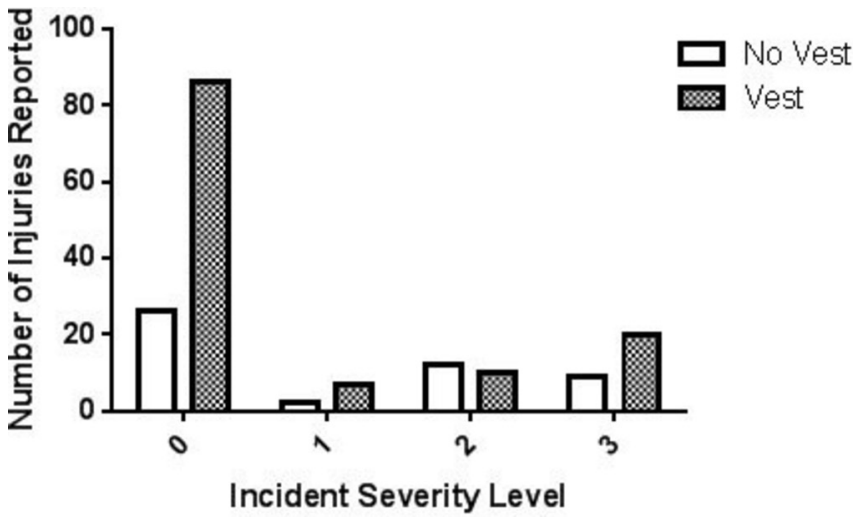

Figure 1 Differences in incident severity level observed when safety vests were worn when riders were participating in cross-country. Each incident was given an ordinal severity level based on information received in the report: $0=$ no injury observed or required no treatment; $1=$ required treatment and continued with activity; $2=$ required treatment but declined to continue with activity; $3=$ serious injury. incident severity level $(\mathrm{p}=0.062)$ when body protection was worn for cross country (figure 1 ). This is likely not statistically significant due to the small sample size with in each incident severity level group (incident severity level $0, \mathrm{n}=112$; level 1, n=9; level 2, n=22; level 3, n=29).

\section{Differences in injuries to the torso of equestrians}

Since body protective vests only cover the torso of the riders, reported injuries involving areas covered by the vests (collarbone, shoulder, ribs, chest, tailbone and so on) were specifically evaluated. Of the 493 incidents in which the rider was not wearing a vest, 232 of the injuries did not involve the torso, 123 of the injuries were reported to involve the torso (24.9\% of incidents; $34.6 \%$ of reported injuries) and 138 did not report details regarding the injuries. Of the 165 incidents in which the rider was wearing a vest and the torso would likely be protected, 63 of the injuries did not involve the torso, 29 of the injuries did involve the torso $(17.6 \%$ of incidents; $31.5 \%$ of reported injuries) and the details regarding the location of injuries were not reported in 73 cases. This suggests that wearing body protective vests may prevent injuries to the rider's torso.

\section{Responses from safety vest survey of USPC membership}

In an effort to better understand the current use and views of safety vests within USPC membership, a survey was developed and distributed to members in 2016. Responses were received from 890 members taking the survey, representing approximately $10 \%$ of the total USPC membership at the time. USPC members progress from beginners (uncertified to the D1, D2 and D3 levels) to intermediate (C1 and C2 levels) and advanced (National level certifications of C3, B and A), and these levels correspond to their degree of riding experience and abilities. While only $72 \%$ of the total responses indicated that the members owned a body protector, $86 \%$ of the members with a D2 certification or higher own one and $93 \%$ of the members with a C-level certification or higher own a body protective vest (figure 2A). Of the members who did not own a vest, $50 \%$ indicated cost as the primary factor, while being unsure of a benefit of wearing one, vests being uncomfortable, and difficulty in fitting were also indicated as reasons for not owning body protection (figure 2B). The majority of members who own one indicated that they wore them only for crosscountry (figure 2C).

\section{Experience level of equestrians relative to degree of injuries reported}

Several studies ${ }^{6} 814$ have reported that injuries are inversely correlated with rider's experience level. To investigate this in our population, the numbers of reported incidents were evaluated at each USPC certification level (figure 3A). Progression through the USPC certification levels is comparable to a members' degree of riding experience and abilities. While the number of reported incidents appears to be greatest in the D2 
A.

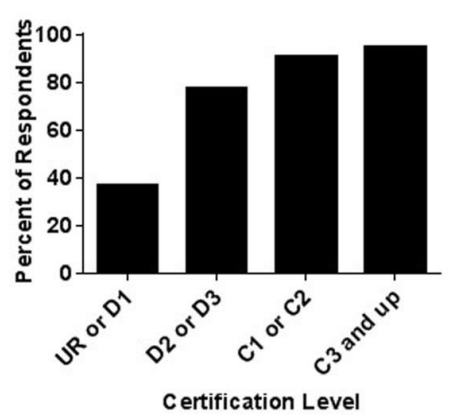

B.

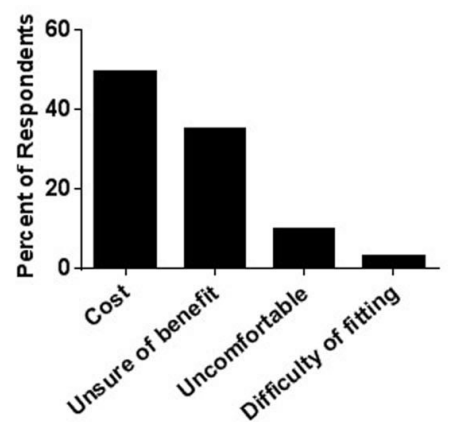

C.

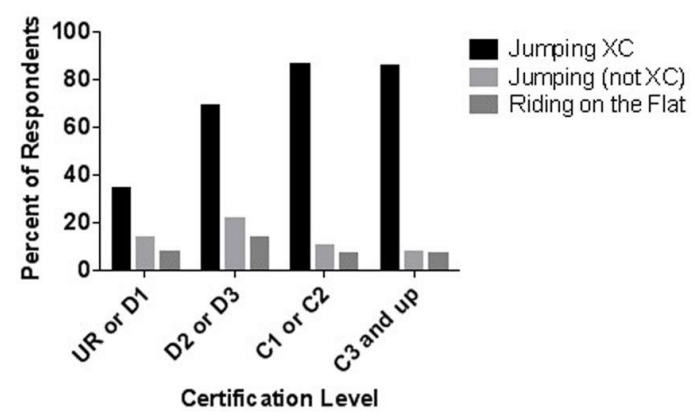

Figure 2 Responses from safety vest survey of USPC membership. (A) Percentage of members that own a body protective vest at the different certification levels; $(B)$ reasons given for the members that do not own a body protector; (C) activities when vests are worn at the different certification levels. USPC, United States Pony Clubs.

and D3 members, it should be noted that those certifications are held by a larger number of members than those with $\mathrm{C}$ level certifications. Therefore, the incidents were normalised to the total number of members at each level (figure $3 \mathrm{~B}$ ). The greatest percentage of incidents after normalisation to the membership is at the D3 level with $1.5 \%$ of the members having an incident, while the intermediate or advanced levels were correlated with a decreased percentage of incidents. The percent of serious injuries out of the total reported incidents at each level ranged from $9.3 \%$ (at the D1 level) to $14.3 \%$ (at the C3 and higher levels, figure 3C). The age of the member was also evaluated at each certification level. Although the median age of an uncertified member is 13.5 years old, the average age of member increases as they progress through the certification levels, for example, D1 is 11, D2 is 13, D3 is 14, C1 is 15, C2 is 16.5 and C3 and higher is 19. Thus, age of the rider was not correlated with increased risk of injury $(\mathrm{p}=0.32)$.

\section{DISCUSSION}

There are few studies that have investigated the effectiveness of wearing body protection by equestrians either when riding on the flat or when jumping. Whitlock ${ }^{11}$ reported that the Irish Jockey Club noticed fewer rib fractures once body protection was worn, but Hessler et $a l^{13}$ was not able to show an association between wearing vests and protection from injuries to the torso. However, this may have been due to the relatively small population of 92 young equestrians investigated in their study, and lack of analysing the effects of body protection when worn during specific activities, such as cross country jumping.

This study used incident report data collected from the USPC where the utilisation of safety vests was not mandatory. There was not a statistically significant difference in injuries observed between the riders wearing vests and those not wearing them in all riding disciplines or when activities were separated into jumping sports (show jumping, jumping phases of eventing and tetrathlon) or

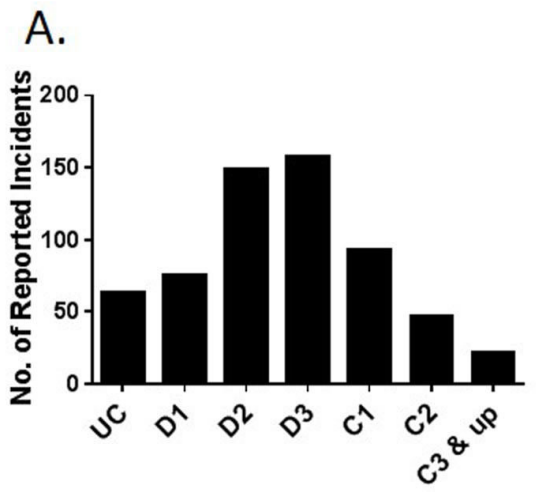

USPC Certification Level

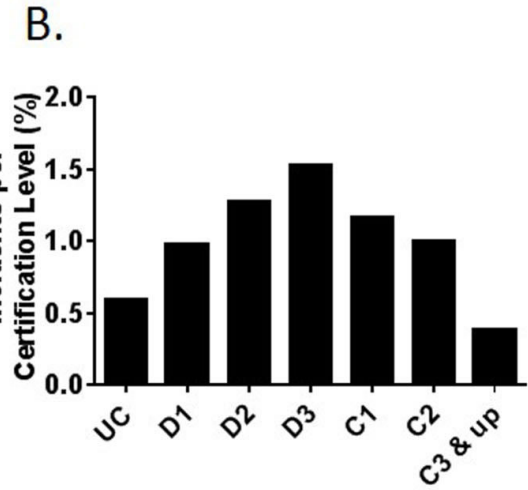

USPC Certification Level

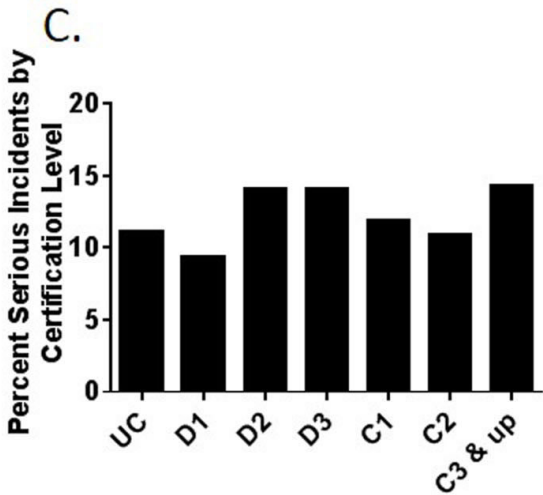

USPC Certification Level

Figure 3 Differences in incidents observed in equestrians with increasing experience levels. (A) Total number of reported incidents at each certification level; (B) number of reported incidents normalised to membership numbers at each certification level; (C) per cent of serious injuries reported at each certification level. USPC, United States Pony Clubs. 
non-jumping sports (dressage, games, polocrosse and so on). However, there was a statistically significant difference observed between riders wearing vests and those not wearing vests when riding cross country, and the riders who wore body protection vests had lower levels of incident severity reported. This may be due to the increased speed, solid nature of the fences, along with other obstacles, such as ditches and water that may cause refusals or falls when participating in the cross country phase of eventing. When specifically evaluating injuries that may be protected by utilisation of safety vests, the per cent of injuries to the torso was similar to previously reported studies. ${ }^{11} 18$

While nearly $75 \%$ of the total membership indicated that they owned a body protector, the percentage of the more advanced riders who owned a vest increased to over $90 \%$. This is likely due to the more advanced riders also competing in national level eventing competitions for which wearing body protection when riding in the cross country phase is required. The majority of members who own a body protector indicated that they wore them only for cross country riding. Of the members who did not own a vest, primary reasons reported included cost, being unsure of a benefit, vests being uncomfortable and difficulty in obtaining a good fit for their body type.

Since several studies ${ }^{6814}$ have reported that less experienced riders are more likely to be injured, USPC members certification levels were also evaluated in the incident report data. The observation that D level members had higher proportions of injuries compared with more experienced riders is similar to that previously reported ${ }^{7}$; however, the percentage of serious injuries did not appear to be correlated with the rider's certification level. The observation that there was a higher number of serious injuries reported at the C3 level and above may be related to the member transitioning from learning to ride horses to training younger/less experienced mounts, leading to additional risks.

The primary limitation of this study is related to reporting compliance, as previously described by O'Brien. ${ }^{16}$ It is suggested that there is an overestimate of serious injuries in incident report data due to non-reporting when a fall leaves a rider uninjured. ${ }^{16}$ USPC has attempted to address this with presentations to local and regional leadership indicating the importance of filling out incident reports any time a rider falls off, and not just when there is an injury.

The USPC participates in several competitive equestrian sports, such as dressage, eventing, show jumping, games, polocrosse, tetrathlon and the unmounted sport of quiz. Additionally members participate in other equestrian disciplines, such as distance riding, driving, fox hunting, hunter seat equitation, vaulting and western. There are dramatic differences in the use of body protection in the different equestrian sports. While the authors know of no published reports indicating a correlation between speed of equestrian activity and increased injuries, that is entirely possible as falling from an increased speed would likely amplify the force applied to the body during a fall. The sports that currently require body protection demand riding at faster speeds, such as racing and the cross country phase of eventing. While the cross country phase of eventing at recognised competitions requires wearing safety vests, the lower numbers of riders wearing vests in disciplines other than eventing are likely due to factors such as the desire to wear traditional riding attire, and the additional heat associated with wearing a vest in warmer climates. The lower numbers of riders wearing vests in other equestrian sports, such as dressage and show jumping, make it difficult to determine statistical significance in this data set.

This study does not address newer pieces of safety equipment commonly known as air vests, in which an air bag is worn over the torso and is deployed when a rider exceeds a certain distance from their saddle, such as during a fall. These vests have only been on the market in the USA for several years, so more data will need to be collected prior to an analysis of their ability to prevent injury.

In summary, while riding and equestrian sports are considered to have a certain degree of risk associated with them, there are ways of making them safer for the rider. Utilisation of safety equipment, such as helmets and body protection, and obtaining education and experience can lessen the chances of having serious injuries associated with falls.

Acknowledgements The authors thank Aileen Gordon, Julie Gragg and Teresa Woods at the National Office of the United States Pony Clubs for their support in providing the incident report data and member survey results used in this study.

Contributors All coauthors of the manuscript have fulfilled the following criteria: substantial contributions to the conception or design of the work, or the acquisition, analysis or interpretation of data; drafting the work or revising it critically for important intellectual content; final approval of the version published; agreement to be accountable for all aspects of the work in ensuring that questions related to the accuracy or integrity of any part of the work are appropriately investigated and resolved.

Funding The authors have not declared a specific grant for this research from any funding agency in the public, commercial or not-for-profit sectors.

Competing interests None declared.

Patient consent Not required.

Ethics approval Our retrospective study was reviewed by the Institutional Review Board at the University of Louisville (17.0290) and was determined to not meet the 'Common Rule' definition of human subjects' research.

Provenance and peer review Not commissioned; externally peer reviewed.

Open access This is an open access article distributed in accordance with the Creative Commons Attribution Non Commercial (CC BY-NC 4.0) license, which permits others to distribute, remix, adapt, build upon this work non-commercially, and license their derivative works on different terms, provided the original work is properly cited, appropriate credit is given, any changes made indicated, and the use is non-commercial. See: http://creativecommons.org/licenses/by-nc/4.0/

\section{REFERENCES}

1. Winkler EA, Yue JK, Burke JF, et al. Adult sports-related traumatic brain injury in United States trauma centers. Neurosurg Focus 2016;40:E4.

2. Zuckerman SL, Morgan CD, Burks S, et al. Functional and structural traumatic brain injury in equestrian sports: a review of the literature. World Neurosurg 2015;83:1098-113. 
3. Lemoine DS, Tate BJ, Lacombe JA, et al. A retrospective cohort study of traumatic brain injury and usage of protective headgear during equestrian activities. $J$ Trauma Nurs 2017;24:251-7.

4. Short SS, Fenton SJ, Scaife ER, et al. Helmet under-utilization by children during equestrian events is associated with increased traumatic brain injury. J Pediatr Surg 2018;53:545-7.

5. Srinivasan V, Pierre C, Plog B, et al. Straight from the horse's mouth: neurological injury in equestrian sports. Neurol Res 2014;36:873-7.

6. Bilaniuk JW, Adams JM, DiFazio LT, et al. Equestrian trauma: injury patterns vary among age groups. Am Surg 2014;80:396-402.

7. Bixby-Hammett DM. Pediatric equestrian injuries. Pediatrics 1992;89(6 Pt 2):1173-6.

8. Guyton K, Houchen-Wise E, Peck E, et al. Equestrian injury is costly, disabling, and frequently preventable: the imperative for improved safety awareness. Am Surg 2013;79:76-83.

9. Papachristos A, Edwards E, Dowrick A, et al. A description of the severity of equestrian-related injuries (ERIs) using clinical parameters and patient-reported outcomes. Injury 2014;45:1484-7.

10. Thomas KE, Annest JL, Gilchrist J, et al. Non-fatal horse related injuries treated in emergency departments in the United States, 2001-2003. Br J Sports Med 2006;40:619-26.
11. Whitlock MR. Injuries to riders in the cross country phase of eventing: the importance of protective equipment. Br J Sports Med 1999;33:212-4

12. Ball CG, Ball JE, Kirkpatrick AW, et al. Equestrian injuries: incidence, injury patterns, and risk factors for 10 years of major traumatic injuries. Am J Surg 2007;193:636-40.

13. Hessler C, Eckert V, Vettorazzi E, et al. Effectiveness of safety vests in pediatric horseback riding. Klin Padiatr 2012;224:443-7.

14. Mayberry JC, Pearson TE, Wiger KJ, et al. Equestrian injury prevention efforts need more attention to novice riders. J Trauma 2007;62:735-9.

15. Camargo F, Gombeski WR, Barger P, et al. Horse-related injuries: causes, preventability, and where educational efforts should be focused. Cogent Food Agric 2018;4.

16. O'Brien D. Look before you leap: what are the obstacles to risk calculation in the equestrian sport of eventing? Animals 2016;6:E13:13.

17. Paix BR. Rider injury rates and emergency medical services at equestrian events. Br J Sports Med 1999;33:46-8.

18. Ekberg J, Timpka T, Ramel $\mathrm{H}$, et al. Injury rates and risk-factors associated with eventing: a total cohort study of injury events among adult Swedish eventing athletes. Int J Inj Contr Saf Promot 2011;18:261-7. 